\title{
Whisper pectoriloquy
}

1.

Deep breath.

head down I'm listening

pads over holes, fingers flexed, poised and ready

to transmit and receive

sounds without vibrations

Please note

there is a confidence issue here

patient speaks quietly into his chest

sound lost in a snail shell, moving at its pace

he's a blacksmith cowboy, carries his tools in his head

and hears only the iron clang of bone on bone

harnesses horse power first

does no harm

second hand over heart

third and fourth

a canter, then a gallop

That's music.

\section{2.}

He forges a dish of ironwood

for lack of steel

charred muscle alloys stronger

His fingernails spoon viscous time from the bowl,

heat tempered with twelve fingers of eau-de-vie

Chewing the fat,

his discourse is jejune, full of blind ends and diversions

and with locked jaw he can only eat words

wrenching them with greater and greater momentum

he gets a gut feeling

flesh around a pit

His ego, deceitful, comes out as a long-winded objection

to the knife \& fork

Sanguine but yellow-bellied: too sanguine, or not enough, he wastes salt

pours water into a gutter

and learns to live with less rust.

\section{3.}

He is inhibited, a reduced alpha male

hairline receding, trying to stand in front of a mountain

He must create gravity

Cloaked in white, he's lily-livered

finds an empty scabbard and buries an acorn

No flowers in the tomb

no chance for abrupt complacency

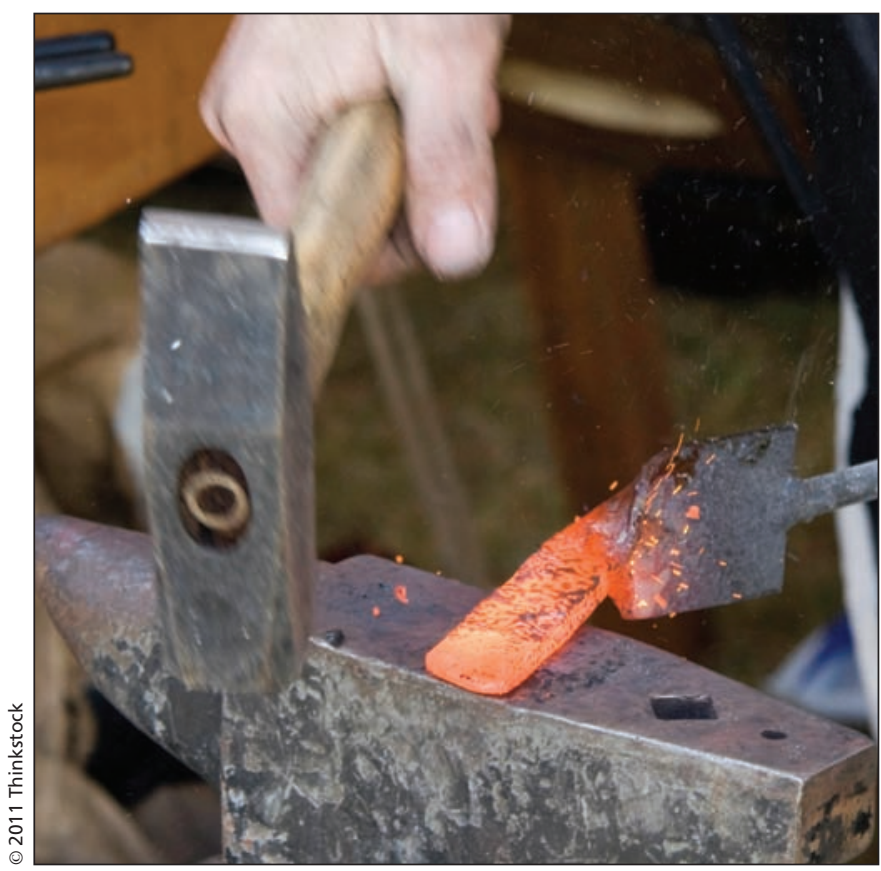

Her ninety-nine complaints -

he uses his hands for ears

Yet they go together and he fills her bowl

with rust, water, salt

Now with narrowed vision

I'm listening to a drum and a bell

and seeing beyond sound

in her the gallop transmutes into two voices

a duet of drummers keeping Galileo's time

one swelling inside the other

and he waits.

\section{Daniel James BSc MA}

Class of 2013

Schulich School of Medicine and Dentistry

University of Western Ontario

London, Ont.

"Whisper pectoriloquy" won second place (poetry) in the 2011 ARS Medica and CMAJ Humanities Poetry and Prose contest. The winners were announced at the 2011 Canadian Conference on Medical Education.

CMAJ 2011. DOI:10.1503/cmaj.111091 